\title{
Evaluation of Phytochemicals and Antioxidant Activity of Gamma Irradiated Quinoa (Chenopodium quinoa)
}

\author{
M. A. Abdelaleem ${ }^{a *}$ (D) and K. R. A. Elbassiony ${ }^{a, b}$ (D) \\ ${ }^{a}$ Atomic Energy Authority, Nuclear Research Center, Plant Research Department, Cairo, Egypt \\ ${ }^{b}$ Huazhong Agricultural University, Food Science and Technology College, Wuhan, China \\ *e-mail: mdabdelrazek.md@gmail.com; mohamed.abdelrazek@eaea.org.egmd
}

Received: December 17, 2019 - Accepted: February 7, 2020 - Distributed: August 31, 2021

With 3 figures

\begin{abstract}
Phytochemical and antioxidant activity of quinoa flour was evaluated after subjected to gamma irradiation processes at dose 3 and $6 \mathrm{kGy}$. Both non-irradiated and irradiated quinoa samples were subjected to successive extractions in ethanol solvent. The antioxidant activity after gamma irradiation treatment was investigated via Ferric reducing antioxidant power (FRAP) and radical-scavenging activity (RSA) using 2,2-diphenyl-1-picrylhydrazyl (DPPH).Total phenolic and flavonoid content were analyzed using Folin-Ciocalteu micro-method, aluminium chloride $\left(\mathrm{AlCl}_{3}\right)$ method and High Performance Liquid Chromatography (HPLC). As well as, effect of irradiation treatment on saponin was also evaluated. Irradiation treatment showed slight differences in the saponin content after exposure to 3 and 6 kGy. Irradiation process enhanced both total phenolic content (TPC) and Total flavonoid content (TFC), TPC were 34.52 and $30.92 \mathrm{mg}$ Gallic Acid Equivalent (GAE)/100g compared to $26.25 \mathrm{mg}$ GAE/100g in non-irradiated quinoa. TFC were 67.44 and $62.89 \mathrm{mg}$ Quercetin Equivalents (QE)/100g compared to $53.15 \mathrm{mg} \mathrm{QE} / 100 \mathrm{~g}$. Irradiation dose $3 \mathrm{kGy}$ significantly $(\mathrm{p}>0.05)$ decreased the $\mathrm{IC}_{50}$ as DPPH-RSA and increased the FRAP.
\end{abstract}

Keywords: Chenopodium quinoa, Gamma Irradiation, polyphenols, antioxidant activity, saponin.

\section{Avaliação de fitoquímicos e atividade antioxidante de quinoa gama irradiada (Chenopodium quinoa)}

\begin{abstract}
Resumo
Atividades fitoquímica e antioxidante da farinha de quinoa foram analisadas após submissão a processos de irradiação gama nas doses 3 e 6 kGy. As amostras de quinoa não irradiadas e irradiadas foram submetidas a extrações sucessivas em solvente etanol. A atividade antioxidante, após o tratamento com irradiação gama, foi investigada por meio do poder antioxidante redutor férrico (ARF) e da atividade de eliminação de radicais (AER) usando 2,2-difenil-1-picril-hidrazil (DPPH). O conteúdo fenólico total e o teor de flavonoide foram analisados usando o método de Folin-Ciocalteu, método de cloreto de alumínio $\left(\mathrm{AlCl}_{3}\right)$ e cromatografia líquida de alta eficiência (CLAE). Além disso, o efeito do tratamento de irradiação na saponina também foi avaliado. O tratamento por irradiação não mostrou diferenças significativas no conteúdo de saponina após exposição a 3 e 6 kGy. O processo de irradiação aumentou o conteúdo fenólico total (CFT) e o teor total de flavonoides (TTF); o CFT foi de 34,52 e 30,92 mg de equivalente de ácido gálico (EAG) / 100 g em comparação com 26,25 mg de EAG / $100 \mathrm{~g}$ na quinoa não irradiada. Os TTF foram 67,44 e 62,89 mg de equivalentes de quercetina (EQ) / $100 \mathrm{~g}$ em comparação com 53,15 mg de EQ / $100 \mathrm{~g}$. A dose de irradiação de 3 kGy diminuiu significativamente $(\mathrm{p}>0,05)$ o $\mathrm{IC}_{50}$ como DPPH-AER e aumentou o ARF.
\end{abstract}

Palavras-chave: Chenopodium quinoa, Irradiação Gama, polifenóis, atividade antioxidante, saponina

\section{Introduction}

So many scientists identified the seeds which not belonging to the grass family as a pseudo-cereal seeds, Quinoa (Chenopodium quinoa) is one of a pseudo-cereal, grown in South America (Andean region). The Food and Agriculture Organization of the United Nations (FAO) launched the year 2013, the "international year of quinoa", as a step in the promotion of planting, harvesting, production, preservation, and consumption of this seeds.

Furthermore, quinoa has been recognized as a nutritious cereal (Vilcacundo and Hernández-Ledesma, 2017).

In a nutritional studies by Fischer et al. (2017) revealed that the quinoa seeds contain high protein with a bioavailable essential amino acids, dietary fibers, complex carbohydrate, lipids with high amount of unsaturated fatty acids, and other bioactive compounds i.e.; polyphenols (flavonoids, lignins, stilbenes, tannins 
and phenolic acids). Moreover, quinoa seeds are an excellent ingredient in healthy and tasty foods. The easy digestibility of quinoa seeds and gluten-free are attributed these seeds as an unusually complete food because they have a well-balanced set of essential amino acids for humans, as well as being a good source of protein, fiber, phosphors, magnesium, and iron.

Recent studies have identified quinoa seeds as a good source of bioactive-polyphenols which might change antioxidant status in the organism and prevent oxidative stress. And, because of that, Phenolic compounds are considered to carry many potential beneficial health effects (Repo-Carrasco-Valencia and Serna, 2011).

The opportunity to supplement or completely replace common cereal grains (corn, rice and wheat) with a pseudo-cereal of higher nutritional value (such as quinoa) is inherently beneficial to the public interests. Unfortunately, quinoa seeds contain bitter-tasting constituents (chiefly water-soluble saponins) located in the outer layers of the seed coat, making it essentially unpalatable. Therefore, most commercial quinoa seeds, have been processed to remove their coating by washing or milling so to eliminate bitter compounds before consumption (Popenoe et al., 1989). Triterpenoid saponins are a diverse group of compounds characterized by the presence of a triterpenoid aglycone backbone $\left(\mathrm{C}_{30} \mathrm{H}_{48}\right)$ with one or more sugar moieties combined to them with ester or glycosidic bonds (Khakimov et al., 2016). Saponins have a astringent taste and bitterness due to their chemical structure. The presence of saponin in food products is not desired and should be reduced to decrease bitterness (Gómez-Caravaca et al., 2014).

For many years ago, irradiation processing was well considered as physical and non-thermal or cold method to preserve foods and food products by exposure of foods to ionizing radiation (Antonio et al., 2012). In study by Behgar et al. (2011) showed that, irradiation may influence the levels of antioxidant phytochemicals either with increased or decreased levels of these plant phytochemicals therefore, gamma irradiation may maintain the antioxidant activity of several plant materials.

In addition, Harrison and Were (2007) found that gamma irradiation increased the phenolic content in almond skin as well as, cinnamon and clove while, the content of phenolic compounds unchanged in nutmeg. On the contrary, other studies by Ahn et al. (2005) revealed that low and medium doses usually have insignificant influence on phytochemical antioxidants where, up to $10 \mathrm{kGy}$ did not have any effect on the antioxidants activity of anise, cinnamon, mint, licorice, nutmeg vanilla and ginger.

Consequently, the employment of quinoa after removal/ reducing of saponin compounds can represent a promising choice leading to additional advantages. In this context, our work aimed to subject quinoa flour to gamma irradiation in order to study the effect of irradiation on the saponin concentration. As well as, study the effect of gamma irradiation on phenolic and flavonoid compounds and antioxidant capacity of quinoa.

\section{Material and Methods}

\subsection{Materials}

Simple samples of quinoa (Chenopodium quinoa) seeds freshly packaged were purchased from Egyptian local health-food store. Quercetin, Folin-Ciocalteu reagent, iron (III) chloride, aluminium chloride and sodium bicarbonate were purchased from Sigma (St. Louis, MO, USA). 2,2-diphenyl-1-picrylhydrazyl (DPPH), sodium acetate trihydrate, glacial acetic acid, (2, 4, 6-tripyridyl-s- triazine, TPTZ), hydrogen chloride, Ferric chloride hexahydrate $\left(\mathrm{FeCl}_{3} .6 \mathrm{H}_{2} \mathrm{O}\right)$ and Ferrous sulfate heptahydrate $\left(\mathrm{FeSO}_{4}\right.$. $7 \mathrm{H}_{2} \mathrm{O}$ ) were purchased from Sigma-Aldrich, Germany. All used chemicals were analytical grade.

\section{Methods}

\subsection{Irradiation treatment}

Fine powder of de-hulled quinoa seeds were irradiated with gamma irradiation at doses of 3 and $6 \mathrm{kGy}$ using an experimental ${ }^{60} \mathrm{Co}$ Gamma chamber (dose rate $665.6 \mathrm{~Gy} / \mathrm{h}$ ), Cyclotron Project, Nuclear Research Center, Atomic Energy Authority, Egypt.

\subsection{Preparation of quinoa extract}

Quinoa seeds were extracted using the procedure of Carciochi et al. (2014) with some modifications. Two gram of quinoa flour samples was extracted with $20 \mathrm{~mL}$ of $80 \%$ ethanol. The mixture was kept in agitation for $30 \mathrm{~min}$ at $160 \mathrm{rpm}$ in an orbital shaker. Then, the homogenate was centrifuged for $10 \mathrm{~min} / 5^{\circ} \mathrm{C}$ at $3500 \mathrm{~g}$ (VS-550, Vision Scientific Co., Ltd., Bucheon Korea) the clarified extract was collected and then subjected to rotary evaporator at $40{ }^{\circ} \mathrm{C}$ under reduced pressure to remove solvent. Finally, the extract was stored in brown bottle and stored at $-18^{\circ} \mathrm{C}$ for further analysis.

\subsection{Determination of Polyphenolic content}

\subsection{Determination of Total Phenolic Content (TPC)}

Total phenolic content of the extracts of both irradiated and non-irradiated quinoa seeds was determined by the Folin-Ciocalteu micro-method (Slinkard and Singleton, 1977). Briefly, $20 \mu \mathrm{l}$ of extract solution were mixed with $1.16 \mathrm{~mL}$ distilled water and $100 \mu \mathrm{l}$ of Folin-Ciocalteu reagent, followed by addition of $300 \mu \mathrm{l}$ of $\mathrm{Na}_{2} \mathrm{CO}_{3}$ solution $(20 \%)$ after $1 \mathrm{~min}$ and before $8 \mathrm{~min}$. Subsequently, the mixture was incubated in a shaking incubator at $40{ }^{\circ} \mathrm{C}$ for $30 \mathrm{~min}$ and its absorbance was measured at $760 \mathrm{~nm}$. The total phenolic content was expressed as gallic acid equivalents (GAE) in milligrams / $100 \mathrm{~g}$ dry material.

\subsection{Determination of Total Flavonoid Content (TFC)}

Total flavonoid content (TFC) of the extracts of both irradiated and non-irradiated quinoa seeds was determined using the aluminium chloride $\left(\mathrm{AlCl}_{3}\right)$ method according to a reliable approach using quercetin as the standard (Ordonez et al., 2006). In this regard, the plant extract 
$(0.1 \mathrm{~mL})$ was added to $0.3 \mathrm{~mL}$ of distilled water followed by addition of $0.03 \mathrm{~mL}$ of $\mathrm{NaNO}_{2}(5 \% \mathrm{w} / \mathrm{v})$. After $5 \mathrm{~min}$. at $25^{\circ} \mathrm{C}, \mathrm{AlCl}_{3}(0.03 \mathrm{~mL}, 10 \%)$ was added. After further $5 \mathrm{~min}$., the reaction mixture was treated with $0.2 \mathrm{~mL}$ of $\mathrm{Na} \mathrm{OH}(1 \mathrm{mM})$. Finally, the reaction mixture was diluted to $1 \mathrm{~mL}$ with water and the absorbance was measured at $510 \mathrm{~nm}$. The results were expressed as quercetin equivalents $(\mathrm{QE})$ in milligram / $100 \mathrm{~g}$ of dry material.

\subsection{Chromatographic analysis of polyphenols compounds}

High Performance Liquid Chromatography (HPLC) analysis was carried out using an Agilent 1260 series. The separation was carried out using Eclipse Plus C18 column (4.6 mm x $250 \mathrm{~mm}$ i.d., $5 \mu \mathrm{m}$ ). The mobile phase consisted of water $(\mathrm{A})$ and $0.02 \%$ tri-floro-acetic acid in acetonitrile (B) at a flow rate $1 \mathrm{~mL} / \mathrm{min}$. The mobile phase was programmed consecutively in a linear gradient as follows: $0 \min (80 \% \mathrm{~A})$; 0 - $5 \mathrm{~min}(80 \% \mathrm{~A}) ; 5-8 \mathrm{~min}$ $(40 \% \mathrm{~A}) ; 8-12 \min (50 \% \mathrm{~A}) ; 12-14 \min (80 \% \mathrm{~A})$ and $14-16 \min (80 \% \mathrm{~A})$. The multi-wavelength detector was monitored at $280 \mathrm{~nm}$. The injection volume was $10 \mu \mathrm{l}$ for each of the sample solutions. The column temperature was maintained at $35^{\circ} \mathrm{C}$.

\subsection{Determination of foaming and foaming index (FI)}

Detection of saponins by foaming test was according to Kokate (1999) with some modifications by Mir et al. (2016), About $2 \mathrm{~g}$ of the powdered sample was boiled in $20 \mathrm{~mL}$ of distilled water in a water bath and filtered. $10 \mathrm{~mL}$ of the filtrate was mixed with $5 \mathrm{~mL}$ of distilled water and shaken vigorously for a stable persistent froth. A two $\mathrm{cm}$ layer of foam indicated the presence of saponins. Foaming index is measured according to methods described by Kozioł (1990a) using the following Equation 1:

Foamin Index $(F 1)=\begin{gathered}1000 \\ a\end{gathered}$

Where: a the volume in $\mathrm{mL}$ of the decoction used for preparing the dilution in the tube where foaming to a height of $1 \mathrm{~cm}$ is observed.

\subsection{Determination of Saponin Percentage}

The saponin content in the samples was evaluated by a semi-quantitative method described by Kozioł (1990a). This method is based on the tensioactive properties of the saponins, which form a stable foam whose height is related to the saponin content in the grains after being dissolved in water and shaken. The percentage of saponins was obtained with following Equation 2:

Saponin $(\%)=\begin{gathered}0.646 \times \text { (height of foam, } \mathrm{cm})-0.104 \\ \text { (weight of the sample, } \mathrm{g}) \times 10\end{gathered}$

\subsection{Determination of Antioxidant Activity}

\subsubsection{Free radical scavenging activity (DPPH・ test)}

The DPPH method of Lee et al. (2003) was used with some modifications. The stock reagent solution (1x $\left.10^{-3} \mathrm{~mol} / \mathrm{L}\right)$ was prepared by dissolving $22 \mathrm{mg}$ of DPPH in $50 \mathrm{~mL}$ of methanol and stored at $-20{ }^{\circ} \mathrm{C}$ until use. quinoa seeds extract $(0.1,0.2,0.2$ and $0.4 \mathrm{mg} / \mathrm{mL})$ and synthetic antioxidant Butylated Hydroxy Toluene (BHT) solution $(0.2 \mathrm{mg} / \mathrm{mL})(0.1 \mathrm{~mL}$ of each) were vortexes for $30 \mathrm{~s}$ with $3.9 \mathrm{~mL}$ of DPPH $\bullet$ solution and left to react for $30 \mathrm{~min}$, after which the absorbance at $517 \mathrm{~nm}$ was recorded. Radical scavenging activity is the method in which the color of the DPPH solution changing from purple to yellow as an indicator of antioxidant activity by radical quenching (Karagözler et al., 2008). A control with no added extract was also analyzed. Results were expressed as a percentage DPPH• radical scavenging activity of a sample and were calculated according to the following Equation 3:

DPPH·radical scavenging activity $(\%)=A b s$ control - Abs sample Abs control

Where, Abs control $=$ the absorbance of DPPH radical + methanol; Abs sample $=$ the absorbance of DPPH radical + samples.

The analyses were done in triplicates and the concentration of extract proportional to a $50 \%$ inhibition of DPPH • radical $\left(\mathrm{IC}_{50}\right)$ was obtained through the analysis of the extract solution concentration versus inhibition percentage graphic. Thus, lower extract concentrations $(\mu \mathrm{g} / \mathrm{mL}, \mathrm{ppm})$ mean greater antioxidant capacity.

\subsection{Ferric reducing antioxidant power (FRAP) assay}

\subsubsection{Reagents preparation}

a) Acetate buffer $300 \mathrm{mM} \mathrm{pH}$ 3.6: Weigh 3.1g sodium acetate trihydrate and add $16 \mathrm{~mL}$ of glacial acetic acid and make the volume to $1 \mathrm{~L}$ with distilled water, b) TPTZ (2, 4, 6-tripyridyl-s- triazine), $10 \mathrm{mM}$ in $40 \mathrm{mM} \mathrm{HCl}$, c) $\mathrm{FeCl}_{3} .6 \mathrm{H}_{2} \mathrm{O}, 20 \mathrm{mM}$. The working FRAP reagent was prepared by mixing $\mathrm{a}, \mathrm{b}$ and $\mathrm{c}$ in the ratio of $(10: 1: 1)$ just before testing. Standard was $\mathrm{FeSO}_{4} .7 \mathrm{H}_{2} \mathrm{O}: 0.1-1.5 \mathrm{mM}$ in methanol.

\subsection{Analytical Procedures}

FRAP solution $(3.6 \mathrm{~mL})$ add to distilled water $(0.4 \mathrm{~mL})$ and incubated at $37^{\circ} \mathrm{C}$ for $5 \mathrm{~min}$. Then this solution mixed with certain concentration of the quinoa extract $(80 \mathrm{~mL})$ and incubated at $37{ }^{\circ} \mathrm{C}$ for $10 \mathrm{~min}$. The absorbance of the reaction mixture was measured at $593 \mathrm{~nm}$. For construction of the calibration curve, five concentrations of $\mathrm{FeSO}_{4} \cdot 7 \mathrm{H}_{2} \mathrm{O}$ $(0.1,0.4,0.8,1,1.12,1.5 \mathrm{mM})$ were used and the absorbance values were measured as for sample solutions (Al-Farsi et al., 2005).

\subsection{Statistical analyses}

All the experiments were carried out in triplicate and mean and standard error were calculated for all data. Then the results were subjected to one-way analysis of variance followed by Duncan's significant differences using SAS program (version 9.1.3) software (Cary, NC). Significant levels were defined as $(\mathrm{P}<0.05)$ (Statistical Analysis System, 2004). 


\section{Results and Discussion}

\subsection{Total phenolic and flavonoid content}

Polyphenols are bioactive secondary plant metabolites that are widely present in commonly consumed foods of plant origin. The main types of polyphenols are flavonoids, and tannins, which act as powerful antioxidants in vitro. Typical phenolics that possess antioxidant activity are known to be mainly phenolic acids and flavonoids. TPC and TFC of quinoa flours were given in Figure 1. As regard, the flavonoid content in all samples either irradiated or non-irradiated was higher than the phenolic content. Similar findings were obtained by Pellegrini et al. (2018) who found that the total flavonoid and phenolic content were 490.2 and $2239 \mathrm{mg} / \mathrm{kg}$, respectively in quinoa seeds.

Our present study revealed that TPC were 26.25, 34.52 and $30.92 \mathrm{mg} \mathrm{GAE} / 100 \mathrm{~g}$ in samples at doses 0 , 3 and $6 \mathrm{kGy}$. These levels tended to be higher than those reported by Park et al. (2017) but lower than Carciochi et al. (2014), Diaz-Valencia et al. (2018), Nsimba et al. (2008), and Pellegrini et al. (2018). On the other hand, TFC were $53.15,67.44$ and $62.89 \mathrm{mg}$ QE/100 $\mathrm{g}$ in samples at doses 0,3 , and $6 \mathrm{kGy}$. the preceding data were higher than those obtained by Carciochi et al. (2014) and Park et al. (2017). These differences might result from the different standards and solvents used in extraction.

The Folin-Ciocalteu procedure is the common method for phenolic content determination, this method does not give quality and quantity of the phenolic compounds in the extracts, in a full picture. However, although all flavonoids are polyphenols, polyphenols not necessarily are flavonoids. As well as, there are many factors affect the polyphenolic compounds (flavonoids and phenols) formation i.e.; genotypes (cultivar and variety), plant maturity, environmental conditions, harvest, and postharvest conditions (Hardman, 2014).

As shown in Table 1 the polyphenols (TPC and TFC) were varied from irradiated and non-irradiated, i.e.; gallic acid slightly increased at dose $6 \mathrm{kGy}$. Our data are in agreement with Kumari et al. (2009) who study the effect of irradiation treatment on the antioxidant activity of Triphala, the gallic acid concentration and total phenolics in water extracts were increased after irradiation thus, antioxidant activity was increased. Catechin was increased from $29.311 \mathrm{mg} / 100 \mathrm{~g}$ in non-irradiated sample to 32.89 and $37.94 \mathrm{mg} / 100 \mathrm{~g}$ in 3 and $6 \mathrm{kGy}$, respectively.

Some polyphenols were totally disappeared after irradiation treatment like; rutin, coumaric acid, vanillin, sinapic, rosemarinic acid, 4',7-DihydroxyisoFlavone and apigenin. These changes in profiling analyses in all samples might be due to exposure to gamma irradiation alter/convert some chemical compounds into another ones as well as, the increased phenolic content due to irradiation treatment could be attributed to the release of phenolic compounds from a glycosidic component and the degradation of larger phenolic compounds into smaller ones by gamma radiation.

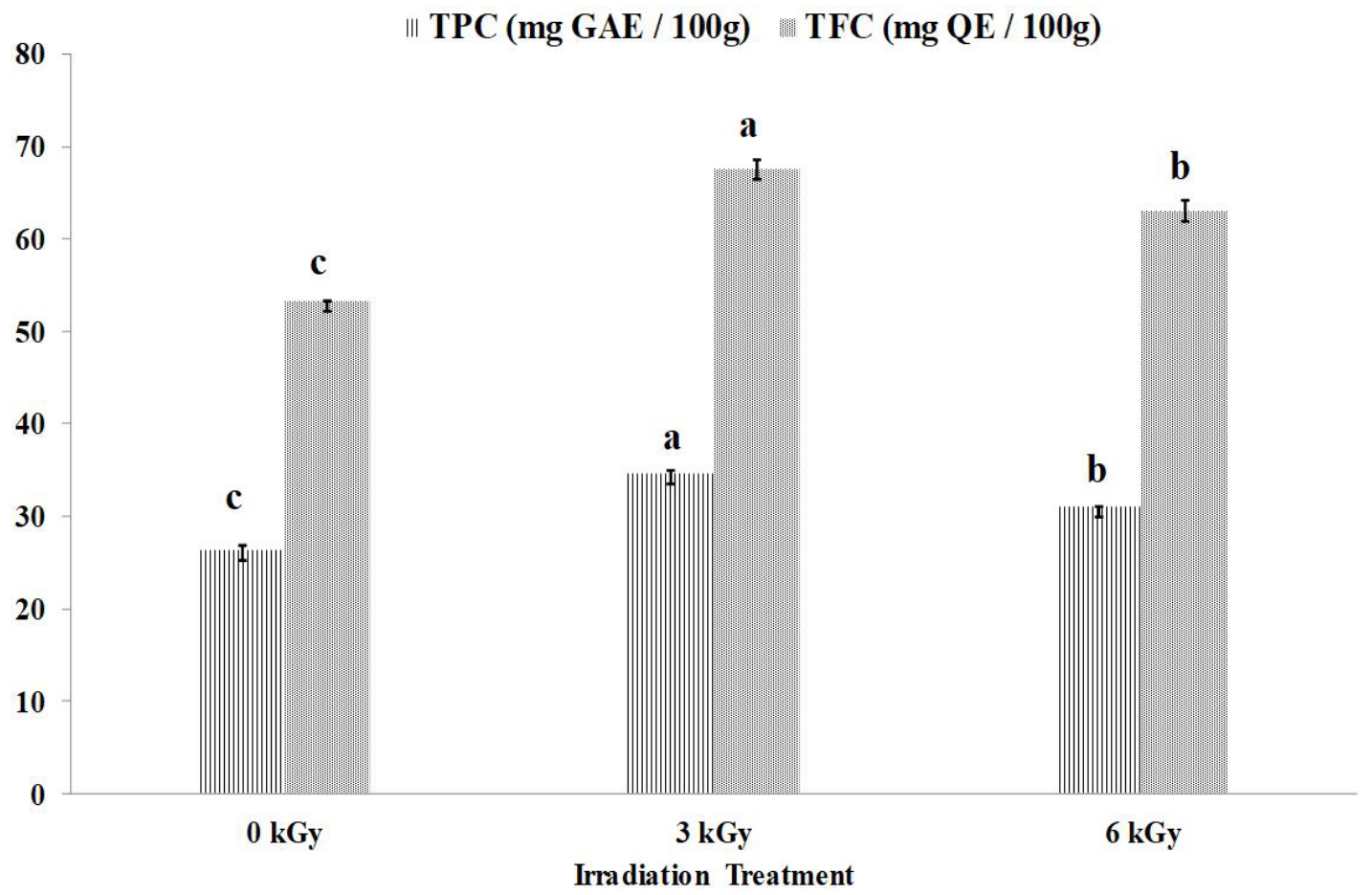

Figure 1. Total Phenolic (TPC) and flavonoid (TFC) content in quinoa seeds. 
Table 1. Chromatographic analysis of phenolic and flavonoid content (mg / $100 \mathrm{~g}$, dry material) in irradiated and non-irradiated quinoa seeds.

\begin{tabular}{|c|c|c|c|}
\hline & \multicolumn{3}{|c|}{ Irradiation Treatments } \\
\hline & 0 kGy & $3 \mathrm{kGy}$ & $6 \mathrm{kGy}$ \\
\hline Gallic acid & 8.92 & 8.355 & 9.60 \\
\hline Catechin & 29.311 & 32.899 & 37.946 \\
\hline Caffeine & ND & ND & ND \\
\hline Caffeic acid & 0.049 & 0.726 & 1.265 \\
\hline Syringic acid & 2.28 & 2.02 & 2.018 \\
\hline Rutin & 0.052 & ND & ND \\
\hline Ellagic acid & 2.024 & 2.073 & 1.820 \\
\hline Coumaric acid & 0.066 & ND & ND \\
\hline Vanillin & 0.286 & ND & ND \\
\hline Ferulic acid & 3.059 & 0.550 & 0.561 \\
\hline Sinapic & 0.245 & ND & ND \\
\hline Chlorogenic acid & $\mathrm{ND}$ & ND & ND \\
\hline Rosmarinic & 0.342 & ND & ND \\
\hline Naringenin & ND & 0.318 & 0.789 \\
\hline Propyl Gallate & 0.350 & 0.778 & 0.779 \\
\hline 4',7-DihydroxyisoFlavone & 0.015 & ND & ND \\
\hline Querectin & 1.842 & 2.036 & 3.041 \\
\hline Apigenin & 0.044 & ND & ND \\
\hline Kaempferol & 1.360 & 1.120 & 1.011 \\
\hline Cinnamic acid & 0.108 & 0.303 & 0.585 \\
\hline $\begin{array}{l}\text { Total Phenols } \\
(\mathrm{mg} / 100 \mathrm{~g}, \mathrm{DM})\end{array}$ & 17.621 & 14.502 & 16.043 \\
\hline $\begin{array}{l}\text { Total Flavonoids } \\
\text { (mg / } 100 \mathrm{~g}, \mathrm{DM})\end{array}$ & 32.732 & 36.676 & 43.372 \\
\hline $\begin{array}{l}\text { Total Polyphenols } \\
\text { (mg / } 100 \text { g, DM) }\end{array}$ & 50.353 & 51.178 & 59.415 \\
\hline
\end{tabular}

$\mathrm{ND}=$ Not Detected, $\mathrm{DM}=$ Dry Material

This point of view, supported by Variyar et al. (2004) who demonstrated that gamma-ray doses of $0.5-5 \mathrm{kGy}$ transformed genistein, an isoflavone glycoside, into its aglycon genistin with increasing radiation dose. As well as, Breitfellner et al. (2002) reported that degradation of phenolic acids (gallic, $\rho$-coumaric, cinnamic and hydroxybenzoic acids) was observed after gamma irradiation at doses from 1 to $10 \mathrm{kGy}$ of strawberries. Different hypothesis was assumed to that degradation one of them, the formation of free hydroxyl $(-\mathrm{OH} \bullet)$ radicals caused decomposition/ hydroxylation to these phenolic acids.

\subsection{Total saponin content}

Different quinoa varieties are classified according to their content of saponin, in regard to saponin concentration, quinoa may be distinguished in; when saponin concentration was

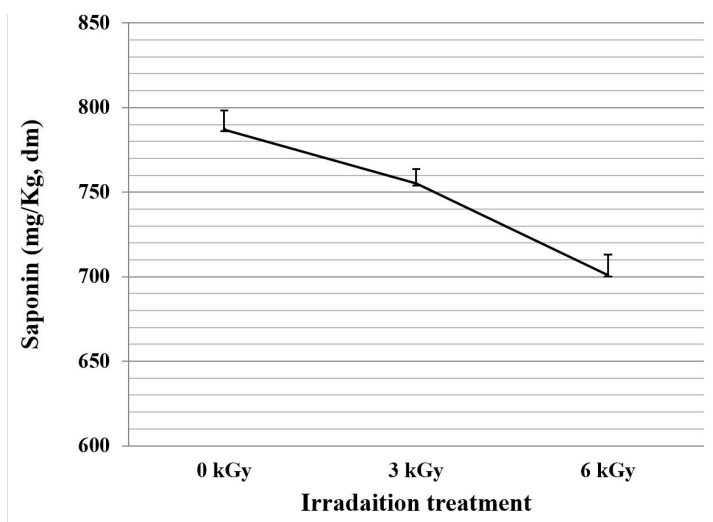

Figure 2. Effect of irradiation treatment on saponin content of quinoa powder.

$0-0.11 \%$ "sweet quinoa" and when saponin concentration is higher than $0.11 \%$ "bitter quinoa" (Martinez et al., 2009).

As shown in Figure 2 saponin content was $787 \mathrm{mg} / \mathrm{kg}$ while the content it was 755 and $701 \mathrm{mg} / \mathrm{kg}$ in quinoa subjected to 3 and $6 \mathrm{kGy}$, respectively. All samples in our study classified on the basis of saponin content present as "sweet" quinoa.

Irradiation treatment showed slight differences in the saponin content after exposure to 3 and $6 \mathrm{kGy}$. These results are completely deferent with Mohamed (2009) who mentioned that the saponin content of Eryngium foetidum L. was increased as gamma irradiation dose increased up to $40 \mathrm{~Gy}$. While the results are agreed with $\mathrm{Na}$ and Lee (2010) when found red ginseng saponins very stable to gamma irradiation.

The most important property of saponin is soap-like or detergent and cause persistent foam when an aqueous decoction is shaken. The foaming ability of an aqueous decoction of herbal materials and their extracts is measured in terms of a foaming index (Shirsat et al., 2017). The foaming index method is the only standard method for quantitative determination of saponin content in plant materials as reported by Kozioł (1990a).

However, our present data also revealed that foaming index in non-irradiated samples (125) where higher than that in irradiated samples (111.1) at both irradiated doses 3 and $6 \mathrm{kGy}$.

\subsection{Antioxidant activity of quinoa seed extract}

\subsubsection{DPPH・Radical scavenging activity}

The antioxidant activity was measured in regard to the radical scavenging, according to the DPPH method (Table, 2). At gamma irradiation dose $3 \mathrm{kGy}$ the DPPHscavenging activity $(0.1$ to $0.4 \mathrm{mg} / \mathrm{mL})$ was $33,47.5,57.3$ and $65.3 \mathrm{mg} / \mathrm{mL}$ compared to non-irradiated 29.3, 40.6, 55.2 and $62.4 \mathrm{mg} / \mathrm{mL}$, respectively. Thus, the irradiation dose up to $3 \mathrm{kGy}$ showed significantly $(\mathrm{p}>0.05)$ increased in DPPH capacity. Gamma irradiation enhanced reactive scavenging capacity of soybean extracts as reported by 
Variyar et al. (2004). While $6 \mathrm{kGy}$ significantly $(\mathrm{p}>0.05)$ decreased the scavenging activity.

The same finding was observed by Moosavi et al. (2014) who found that $2 \mathrm{kGy}$ slightly increased radical scavenging activity of almond hull and the lowest values of scavenging activity was observed at $10 \mathrm{kGy}$. Antioxidant content of fresh plant is either increased or decreased due to radiation treatment, and the radiation is dependent on exposure time, raw material and dose absorbed (Bhat et al., 2007).

Our obtained data are similar to Brand-Williams et al. (1995) in the higher levels of DPPH antiradical activity in samples that were subjected to irradiation treatment correlated with higher levels of phenolic and flavonoid. Most of the plant extracts which have antioxidant activity is related to its content of different phenolic compounds.

These compounds are commonly contain at least one hydroxyl substituted aromatic ring system, that can easily oxidized, in addition serving as important units for donating ability on DPPH to produce DPPH-H, considered as an essential mechanism of antioxidants. Moreover, irradiation especially at low doses results in the intracellular generation of hydrogen peroxide and reactive oxygen species (ROS), which may alter the plant antioxidant content (Kovacs and Keresztes, 2002).

Antioxidant capacity can be measured as inhibitory concentration $50\left(\mathrm{IC}_{50}\right)$, which is the concentration required to get $50 \%$ antioxidant capacity measured as DPPH. The Lower the $\mathrm{IC}_{50}$ values the higher the radical scavenging activity gained. Figure 3 showed the $\mathrm{IC}_{50}$ of irradiated and non-irradiated quinoa. Three $\mathrm{kGy}$ represented the lowest $\mathrm{IC}_{50}(0.217 \mathrm{mg} / \mathrm{mL})$ compared to both non-irradiated $(0.24 \mathrm{mg} / \mathrm{mL})$ and quinoa applied to $6 \mathrm{kGy}(0.282 \mathrm{mg} / \mathrm{mL})$.

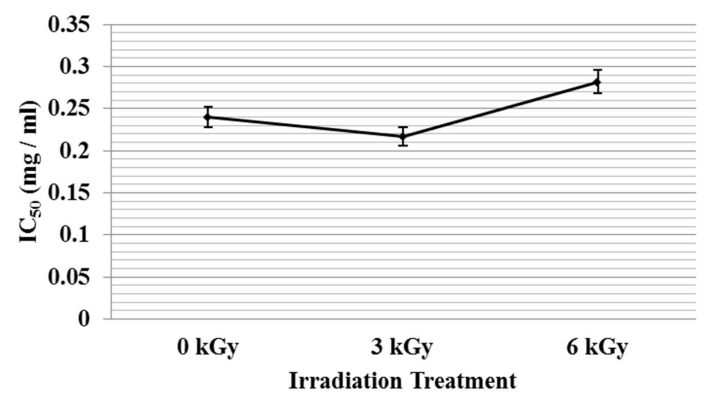

Figure 3. Radical Scavenging activity (DPPH $\left.\mathrm{IC}_{50}, \mathrm{mg} / \mathrm{mL}\right)$ of irradiated and non-irradiated quinoa.
Nsimba et al. (2008) who worked on different ecotypes of quinoa, from Japan and Bolivia highlands, presented $\mathrm{IC}_{50}$ values between $100-7500 \mu \mathrm{g} / \mathrm{mL}$ (ecotypes of Japan) and $300-15800 \mu \mathrm{g} / \mathrm{mL}$ (ecotypes of Bolivia Altiplano). Alvarez-Jubete et al. (2010b) and Nsimba et al. (2008) mentioned that the antioxidant activity of quinoa is varied according to differences of its ecotypes, where the presence of phenolic compounds was influenced by different factors i.e.; genetic factors, agrotechnical process, and environmental conditions.

\subsubsection{Ferric Reducing Antioxidant Power (FRAP)}

The FRAP assay depends on the reduction of ferric TPTZ [Fe (III)-TPTZ] to ferrous TPTZ [Fe (II)-TPTZ], which has an intensive blue color and can be monitored at $593 \mathrm{~nm}$, by a reductant either reducing agents or antioxidants, at low pH (Xu and Chang, 2007).

The FRAP values for the quinoa seed extract are presented in Table 2. The quinoa seed extract exhibited the highest FRAP value with $6.29 \mathrm{mM} \mathrm{Fe}^{2+} / \mathrm{kg}$ dry material at gamma irradiated dose $3 \mathrm{kGy}$, followed by $6 \mathrm{kGy}$ $\left(5.86 \mathrm{mM} \mathrm{Fe}^{2+} / \mathrm{kg}\right.$ dry material), and non-irradiated quinoa (5.49 $\mathrm{mM} \mathrm{Fe}^{2+} / \mathrm{kg}$ dry material). Furthermore, all FRAP data in our present study increased in irradiated quinoa compared to non-irradiated. The FRAP values of quinoa seed extracts were closer to the values previously reported by Nsimba et al. (2008), whereas the FRAP value of quinoa seed extract in the present study was higher than obtained by Brend et al. (2012). Furthermore, the obtained results illustrated that there was a correlation between phenolic contents and ferric reducing antioxidant power. This finding declared that the importance of phenolic acids content as a reducing agent in our study and this may be due to their potent electron donating abilities (Bilto et al., 2012).

Radiation treatments have been shown to either increase or decrease the antioxidant content of fresh plant produce, which is dependent on the dose delivered, exposure time, and the raw material used. The enhanced antioxidant capacity/activity (correlation with the total phenolic content accordingly antibacterial activity) of a plant after irradiation is mainly attributed either to increase enzyme activity (e.g., phenylalanine ammonialyase and peroxidase activity) or to the increased extractability from the tissues (Bhat et al., 2007).

In addition, Khattak et al. (2008) mentioned that the antioxidant activity was either increased or decreased of

Table 2. Antioxidant activity of irradiated and non-irradiated quinoa.

\begin{tabular}{lccccc}
\hline & FRAP $(\mathbf{m M}$ & \multicolumn{4}{c}{ DPPH $(\mathbf{m g} / \mathbf{m L})$} \\
\cline { 3 - 6 } & $\left.\mathbf{F e}^{2+} / \mathbf{~ k g}, \mathbf{d m}\right)$ & $\mathbf{0 . 1}$ & $\mathbf{0 . 2}$ & $\mathbf{0 . 3}$ & $\mathbf{0 . 4}$ \\
\hline $0 \mathrm{kGy}$ & $5.49 \pm 0.31^{\mathrm{a}}$ & $29.3 \pm 0.51^{\mathrm{a}}$ & $40.6 \pm 0.37^{\mathrm{b}}$ & $55.2 \pm 0.49^{\mathrm{a}}$ & $62.4 \pm 0.73^{\mathrm{a}}$ \\
$3 \mathrm{kGy}$ & $6.29 \pm 0.27^{\mathrm{a}}$ & $33.0 \pm 2.32^{\mathrm{a}}$ & $47.5 \pm 0.43^{\mathrm{a}}$ & $57.3 \pm 0.65^{\mathrm{a}}$ & $65.3 \pm 0.89^{\mathrm{a}}$ \\
$6 \mathrm{kGy}$ & $5.86 \pm 0.07^{\mathrm{a}}$ & $30.1 \pm 1.01^{\mathrm{a}}$ & $39.6 \pm 0.50^{\mathrm{b}}$ & $42.5 \pm 0.98^{\mathrm{b}}$ & $53.8 \pm 0.94^{\mathrm{b}}$ \\
\hline
\end{tabular}

Each value represents the mean \pm S.E., the mean value with different superscript alphabets in the same column indicate significant differences $(\mathrm{P}<0.05)$ using Duncan test, FRAP (ferric reducing antioxidant power), dm (dray matter), DPPH (1,1-diphenyl-2picrylhydrazyl). 
irradiated samples might be due to the different of solvents used for extraction. However, the scavenging activity was enhanced after irradiation treatment.

\section{Conclusion}

Quinoa seeds contain high amount of polyphenols and tends to have potent antioxidant capacity. In general, gamma irradiation changed the phytochemical content and antioxidant activity of quinoa seeds flour. $3 \mathrm{kGy}$ was the enhancement dose to maintain antioxidant content and activity. Regarding the saponin, it tends to be resistance to many processes and so gamma irradiation and calls for further investigations.

\section{References}

AHN, H.J., KIM, J.H., KIM, J.K., KIM, D.H., YOOK, H.S. and BYUN, M.W., 2005. Combined effects of irradiation and modified atmosphere packaging on minimally processed Chinese cabbage (Brassica rapa L.). Food Chemistry, vol. 89, no. 4, pp. 589-597. http://dx.doi.org/10.1016/j.foodchem.2004.03.029.

AL-FARSI, M., ALASALVAR, C., MORRIS, A., BARON, M. and SHAHIDI, F., 2005. Comparison of antioxidant activity, anthocyanins, carotenoids, and phenolics of three native fresh and sun-dried date (Phoenix dactylifera $\mathrm{L}$.) varieties grown in Oman. Journal of Agricultural and Food Chemistry, vol. 53, no. 19, pp. 7592-7599. http://dx.doi.org/10.1021/jf050579q. PMid:16159191.

ALVAREZ-JUBETE, L., WIJNGAARD, H., ARENDT, E.K. and GALLAGHER, E., 2010b. Polyphenol composition and in nitro antioxidant activity of amaranth, quinoa, buckwheat and wheat as affected by sprouting and baking. Food Chemistry, vol. 119, no. 2, pp. 770-778. http://dx.doi.org/10.1016/j.foodchem.2009.07.032.

ANTONIO, A.L., CAROCHO, M., BENTO, A., QUINTANA, B., LUISA BOTELHO, M. and FERREIRA, I.C., 2012. Effects of gamma radiation on the biological, physicochemical, nutritional and antioxidant parameters of chestnuts - A review. Food and Chemical Toxicology, vol. 50, no. 9, pp. 3234-3242. http://dx.doi. org/10.1016/j.fct.2012.06.024. PMid:22735498.

BEHGAR, M., GHASEMI, S., NASERIAN, A., BORZOIE, A. and FATOLLAHI, H., 2011. Gamma radiation effects on phenolics, antioxidants activity and in vitro digestion of pistachio (Pistachia vera) hull. Radiation Physics and Chemistry, vol. 80, no. 9, pp. 963-967. http://dx.doi.org/10.1016/j.radphyschem.2011.04.016.

BHAT, R., SRIDHAR, K.R. and TOMITA-YOKOTANI, K., 2007. Effect of ionizing radiation on antinutritional features of velvet bean seeds (Mucuna pruriens). Food Chemistry, vol. 103, no. 3, pp. 860-866. http://dx.doi.org/10.1016/j.foodchem.2006.09.037.

BILTO, Y.Y., SUBOH, S., ABURJAI, T. and ABDALLA, S., 2012. Structure-activity relationships regarding the antioxidant effects of the flavonoids on human erythrocytes. Nature and Science, vol. 9, pp. 740-747.

BRAND-WILLIAMS, W., CUVELIER, M.E. and BERSET, C., 1995. Use of free radical method to evaluate antioxidant activity. Food Science and Technology, vol. 28, pp. 25-30

BREITFELLNER, F., SOLAR, S. and SONTAG, G., 2002. Effect of $\gamma$-irradiation on phenolic acids in strawberries. Journal of Food Science, vol. 67, no. 2, pp. 517-521. http://dx.doi. org/10.1111/j.1365-2621.2002.tb10629.x.
BREND, Y., GALILI, L., BADANI, H., HOVAV, R. and GALILI, S., 2012. Total phenolic content and antioxidant activity of red and yellow quinoa (Chenopodium quinoa Willd.) seeds as affected by baking and cooking conditions. Food and Nutrition Sciences, vol. 3, no. 08, pp. 1150-1155. http://dx.doi.org/10.4236/fns.2012.38151.

CARCIOCHI, R.A., MANRIQUE, G.D. and DIMITROV, K., 2014. Changes in phenolic composition and antioxidant activity during germination of quinoa seeds (Chenopodium quinoa Willd.). International Food Research Journal, vol. 21, no. 2, pp. 767-773.

DIAZ-VALENCIA, Y.K., ALCA, J.J., CALORI-DOMINGUES, M.A., ZANABRIA-GALVEZ, S.J. and CRUZ, S.H.D., 2018. Nutritional composition, total phenolic compounds and antioxidant activity of quinoa (Chenopodium quinoa Willd.) of different colors. Nova Biotechnology Chimica, vol. 17, no. 1, pp. 74-85. http://dx.doi.org/10.2478/nbec-2018-0008

FISCHER, S., WILCKENS, R., JARA, J., ARANDA, M., VALDIVIA, W., BUSTAMANTE, L., GRAFA, F. and OBALA, I., 2017. Protein and antioxidant composition of quinoa (Chenopodium quinoa Willd.) sprout from seeds submitted to water stress, salinity and light condition. Industrial Crops and Products, vol. 107, pp. 558-564. http://dx.doi.org/10.1016/j.indcrop.2017.04.035.

GÓMEZ-CARAVACA, A.M., IAFELICE, G., VERARDO, V., MARCONI, E. and CABONI, M.F., 2014. Influence of pearling process on phenolic and saponin content in quinoa (Chenopodium quinoa Willd). Food Chemistry, vol. 157, pp. 174-178. http:// dx.doi.org/10.1016/j.foodchem.2014.02.023. PMid:24679767.

HARDMAN, E.H., 2014. Diet components can suppress inflammation and reduce cancer risk. Nutrition Research and Practice, vol. 8, no. 3, pp. 233-240. http://dx.doi.org/10.4162/ nrp.2014.8.3.233. PMid:24944766.

HARRISON, K. and WERE, L., 2007. Effect of gamma irradiation on total phenolic content yield and antioxidant capacity of almond skin extracts. Food Chemistry, vol. 102, no. 3, pp. 932-937. http:// dx.doi.org/10.1016/j.foodchem.2006.06.034.

KARAGÖZLER, A.A., ERDAĞ, B., EMEK, Y.C. and UYGUN, D.A., 2008. Antioxidant activity and proline content of leaf extracts from Dorystoechas hastata. Food Chemistry, vol. 111, no. 2, pp. 400-407. http://dx.doi.org/10.1016/j.foodchem.2008.03.089. PMid:26047442.

KHAKIMOV, B., TSENG, L.H., GODEJOHANN, M., BAK, S. and ENGELSEN, S.B., 2016. Screening for triterpenoid saponins in plants using hyphenated analytical platforms. Molecules (Basel, Switzerland), vol. 21, no. 12, pp. 1614. http://dx.doi.org/10.3390/ molecules21121614. PMid:27886152.

KHATTAK, K.F., SIMPSON, T.J. and IHASNULLAH., 2008. Effect of gamma irradiation on the extraction yield, total phenolic content and free radical-scavenging activity of Nigella staiva seed. Food Chemistry, vol. 110, no. 4, pp. 967-972. http://dx.doi. org/10.1016/j.foodchem.2008.03.003. PMid:26047287.

KOKATE, C.K., 1999. Practical Pharmacognosy. New Delhi, India: Vallabh Prakashan Publication, 222 p.

KOVACS, E. and KERESZTES, A., 2002. Effect of gamma and UV-B/C radiation on plant cells. Micron (Oxford, England), vol. 33, no. 2, pp. 199-210. http://dx.doi.org/10.1016/S09684328(01)00012-9. PMid:11567888.

KUMARI, N., KUMAR, P., MITRA, D., PRASAD, B., TIWARY, B.N. and VARSHNEY, L., 2009. Effects of ionizing radiation on microbial decontamination, phenolic contents, and antioxidant properties of triphala. Journal of Food Science, vol. 74, no. 3, pp. M109-M113. http://dx.doi.org/10.1111/j.1750-3841.2009.01079.x. PMid:19397725. 
KOZIOŁ, M.J., 1990a. Desarrollo del método para determinar el contenido de saponinas en la quinua. In C. WAHLI, ed. Quinua: Hacia su cultivo comercial. Quito: Latinreco, pp. 175-185.

LEE, S.C., KIM, J.H., JEONG, S.M., KIM, D.R., HA, J.U., NAM, K.C. and AHN, D.U., 2003. Effect of far-infrared radiation on the antioxidant activity of rice hulls. Journal of Agricultural and Food Chemistry, vol. 51, no. 15, pp. 4400-4403. http://dx.doi. org/10.1021/jf0300285. PMid:12848517.

MARTINEZ, E.A., VEAS, E., JORQUERA, C., SAN MARTIN, R. and JARA, P., 2009. Re-introduction of Chenopodium quinoa Willd. into arid Chile: Cultivation of two lowland races under extremely low irrigation. Journal Agronomy \& Crop Science, vol. 195, pp. 1-10. http://dx.doi.org/10.1111/j.1439037X.2008.00332.x.

MIR, M.A., PARIHAR, K., TABASUM, U. and KUMARI, E., 2016. Estimation of alkaloid, saponin and flavonoid, content in various extracts of Crocus sativa. Faslnamah-i Giyahan-i Daruyi, vol. 4 , no. 5 , pp. $171-174$.

MOHAMED, A.A., 2009. Effect of low dose gamma irradiation on some phytochemicals and scavenger ability of in vitro Culantro (Eryngium foetidum L.) plantlets. Medicinal and Aromatic Plant Science and Biotechnology, vol. 3, no. 1, pp. 32-36.

MOOSAVI, K.S., HOSSEINI, S., DEHGHAN, G. and JAHANBANESFAHLAN, A., 2014. The effect of gamma irradiation on phytochemical content and antioxidant activity of stored and none stored almond (Amygdalus communis L.) Hull. Pharmaceutical Sciences, vol. 20, pp. 102-106.

NA, Y.-C. and LEE, D.-U., 2010. Analysis of ginseng saponin content after proton beam irradiation. Journal of the Korean Physical Society, vol. 56, no. 4, pp. 1190-1193. http://dx.doi. org/10.3938/jkps.56.1190.

NSIMBA, R.Y., KIKUZAKI, H. and KONISHI, Y., 2008. Antioxidant activity of various extracts and fractions of Chenopodium quinoa and Amaranthus spp. seeds. Food Chemistry, vol. 106, no. 2, pp. 760-766. http://dx.doi.org/10.1016/j.foodchem.2007.06.004.

ORDOÑEZ, A.A.L., GOMEZ, J.D., VATTUONE, M.A. and LSLA, M.I., 2006. Antioxidant activities of Sechium edule (Jacq.) Swartz extracts. Food Chemistry, vol. 97, no. 3, pp. 452-458. http://dx.doi.org/10.1016/j.foodchem.2005.05.024.
PARK, J.H., LEE, Y.J., KIM, Y.H. and YOON, K.S., 2017. Antioxidant and antimicrobial activities of Quinoa (Chenopodium quinoa Willd.) seeds cultivated in Korea. Preventive Nutrition and Food Science, vol. 22, no. 3, pp. 195-202. PMid:29043217.

PELLEGRINI, M., LUCAS-GONZALES, R., RICCI, A., FONTECHA, J., FERNÁNDEZ-LÓPEZ, J., PÉREZ-ÁLVAREZ, J.A. and VIUDA-MARTOS, M., 2018. Chemical, fatty acid, polyphenolic profile, techno-functional and antioxidant properties of flours obtained from quinoa (Chenopodium quinoa Willd) seeds. Industrial Crops and Products, vol. 111, pp. 38-46. http:// dx.doi.org/10.1016/j.indcrop.2017.10.006.

POPENOE, H., KING, S.R., LEÒN, J. and SUMARKAUNOWSK, L. 1989. National Research Council. Lost crops of the Incas. In little known plants of the Andes with promise for world-wide cultivation. Washington, DC: National Academy Press. pp. 149-162.

REPO-CARRASCO-VALENCIA, R.A.-M. and SERNA, L.A., 2011. Quinoa (Chenopodium quinoa, Willd.) as a source of dietary fiber and other functional components. Food Science and Technology, vol. 31, no. 1, pp. 225-230. http://dx.doi.org/10.1590/S0101-20612011000100035.

STATISTICAL ANALYSIS SYSTEM, 2004. SAS User, s Guide Release. 6.04 Ed. Cary, NC: Statistics SAS institute Inc.

SHIRSAT, M.K., DWIVEDI, J., KHATHURIYA, R. and WADHAVE, M.A. 2017. Practical handbook of pharmacognosy. Dhayari: Success Publications, 144 p.

SLINKARD, K. and SINGLETON, V.L., 1977. Total phenol analysis: Automation and comparison with manual methods. American Journal of Enology and Viticulture, vol. 28, pp. 49-55.

VARIYAR, P.S., LIMAYE, A. and SHARMA, A., 2004. Radiationinduced enhancement of antioxidant content of soybean (Glycine max Merrill). Journal of Agricultural and Food Chemistry, vol. 52, no. 11, pp. 3385-3388. http://dx.doi.org/10.1021/jf030793j. PMid:15161202.

VILCACUNDO, R. and HERNÁNDEZ-LEDESMA, B., 2017. Nutritional and biological value of quinoa (Chenopodium quinoa Willd.). Current Opinion in Food Science, vol. 14, pp. 1-6. http:// dx.doi.org/10.1016/j.cofs.2016.11.007.

XU, B. and CHANG, S., 2007. A comparative study on phenolic profiles and antioxidant activities of legumes as affected by extraction solvents. Journal of Food Science, vol. 72, no. 2, pp. S159-S166. http://dx.doi.org/10.1111/j.1750-3841.2006.00260.x. PMid:17995858. 